\title{
Enhancing the practice learning experiences of BME students: Strategies for practice education
}

\section{Prospera Tedam ${ }^{1}$}

\begin{abstract}
Practice learning, also known as field education or practicum is central to social work education not only in the UK, but also in countries such as the United States of America, Australia, New Zealand, Canada and South Africa. It presents students with opportunities to integrate academic learning and practice experience with people, their families, communities and environments, and enables the development and enhancement of key skills and social work values. In England, recent studies have highlighted the disparity between black students and white students in terms of progression and attainment on social work qualifying programmes, and practice placements are becoming notorious as sites of difficulty for many students from black and minority ethnic (BME) backgrounds. This paper focuses on a sub-group (black African students), an ethnic minority group with a unique set of characteristics which have been found to contribute to their specific experiences of practice education in the UK.

This paper outlines some strategies which have been proposed by black African students as necessary and central to enhancing their practice learning experiences and outcomes on social work programmes. This article was developed from a paper presented to the International Conference on Practice Learning in Scotland (4-7 April 2014).
\end{abstract}

Keywords: practice learning; black students; positive outcomes; successful placements

1. Senior Lecturer in Social Work \& University Teaching Fellow University of Northampton

Address for correspondence: Prospera.Tedam@northampton.ac.uk 


\section{Introduction}

In the field, students have the opportunity to test what they learn in the classroom; integrate theory with practice; evaluate the effectiveness of interventions; contend with the realities of social, political and economic injustice; strive for cultural sensitivity and competence; deliberate on the choices posed by ethical dilemmas; develop a sense of self in practice; and build a connection to and identity with the profession (Valentine, 2004, p.3).

Valentine's statement is what social work practice learning should be about, yet some minority groups find that they are spending their time challenging or fending off discrimination, oppression and racism that exists and is reproduced by the power structures within the practice learning environment (Gair et al, 2014).

The progression and attainment of black and minority ethnic (BME) students in higher education is well documented in the UK and elsewhere (Shiner and Modood, 2002; Richardson, 2008; NUS, 2011). In the UK, studies have highlighted the growing gap in progression and attainment between black students and their white peers in institutions of higher education. The reasons advanced for the progression and attainment gap are varied, as are the strategies proposed for minimising the gap. The heterogeneous nature of this group calls for nuanced strategies and responses to address the disparity effectively.

Research suggests that social work education in the UK is producing differential outcomes between white students and their black peers (Hussein et al, 2008, 2009; Bernard et al, 2011, 2013; Fairtlough et al, 2013; Fletcher et al, 2013; Tedam, 2014). Of particular concern are the growing numbers of black African students who are reported to be taking longer to complete their studies and/or graduating with lower degree classifications (GSCC, 2012). In an attempt to address this, black African students in one English higher education institution (HEI) developed a black African student support group which they named 'Padare', a Zimbabwean word which means 'meeting place' (Bartoli et al, 2008). This support group has contributed to the empowerment of black African students, and resulted in improved academic outcomes and significant gains in their attitudes and confidence in contributing in lectures (Bartoli, 2013).

This paper draws upon a small qualitative study into the placement experiences of black African students in which a number of strategies were proposed to enhance not only their experiences of practice education but

131 J. of Practice Teaching \& Learning 13(2-3), pp.130-145. ๑ wE-b 
also the overall outcomes of their social work qualifying training. These strategies will be examined under three main areas in relation to the student, the HEI and the practice educator (PE). The findings from this small-scale study have been reported elsewhere (Tedam, 2014) and so this current paper will highlight some of the ideas proposed by participants as facilitators of success for this ethnic minority group, an area of social work research which is sparse.

According to Johnson-Ahorlu (2012), it is not uncommon for narratives about experiences of racism to be viewed by the majority group with doubt rather than a resource for learning. The two participants in this study have been given pseudonyms - Ramatu and Shola - and it is important to discuss their profiles. Both are female, come from countries in West Africa and had lived in the UK for over ten years. One was deemed a 'home' student and the other an international student for the purposes of fees and other course-related costs. They attended different HEIs in the Midlands, both studying on an undergraduate social work programme. However, one participant already had a related social science undergraduate degree.

Walter et al (2011) have argued that the social work curriculum engages with a range of emancipatory theories and concepts such as anti-oppressive and anti-racist theory, critical theory and feminist theory, and that this can result in a false sense of security about the ways in which social work engages with service users and colleagues in terms of diversity and difference. Applying this to social work education, the experiences and narratives of Shola and Ramatu affirm the view that social work education does not insulate students from experiencing racism, discrimination or disadvantage.

\section{Literature review}

There is a plethora of literature identifying strategies and processes which enhance the student experience of higher education and that can contribute to positive and successful learning experiences for students. These strategies include an active and engaging curriculum content and pedagogy (Thomas, 2012), institutional commitment (Yorke and Longden, 2008), enhancing student engagement and reducing isolation (Jones and Thomas, 2005). In relation to BME students, Singh (2011) reported that this group are more likely to succeed in universities where institutional policies promote

132 J. of Practice Teaching \& Learning 13(2-3), pp.130-145. @ w\&b 
cohesion amongst the different ethnic groups represented. This view is supported by Dhanda (2010) whose study into the experiences of BME students at a university in the West Midlands uncovered low expectations of BME students by staff, a perception of unfairness in the assessment and moderation processes and a lack of support from tutors as contributing to the disparity in attainment between them and their white peers.

With specific reference to BME students of social work, Goldingay (2012) proposes that in order to enhance their placement experiences HEIs spend time in pre-placement planning and support, particularly for international students, as her research evidenced the value of such a strategy. It has been argued elsewhere (Tedam, 2012a) that the use of culturally relevant case studies can support and develop the social work knowledge base for specific ethnic minority students. Hair and O'Donoghue (2009) have suggested that social work supervision has the potential to contribute to the 'marginalization of people according to cultural identities such as ethnicity, race, gender, or class' (p.71) and in order to address this, the MANDELA model (Tedam, 2012b) was developed to support anti-oppressive practice supervision. Field et al (2014) subsequently cited the MANDELA model as an anti-oppressive and strengths-based approach that practice educators might find helpful in understanding and appreciating differences and similarities which some students bring to placement and which can be used creatively to enhance placement experiences.

Practice educators and supervisors are required to adhere to values which reflect core anti-oppressive and anti-discriminatory principles (TCSW, 2012) with an emphasis on assessing in a manner that evidences understanding and respect for diversity. The role of the PE in social work has undergone a number of changes (TCSW, 2012) resulting in the development of practice educator professional standards (PEPS), which are minimum standards that guide PEs to 'teach, supervise and assess learners' in line with the Professional Capability Framework (PCF). In addition to these standards, PEs are expected to work to specific values in relation to the assessment of students. Of relevance to this paper are the eight values (TCSW, 2012) and the specific value which requires PEs to

assess in a manner that does not stigmatise or disadvantage individuals and ensures equality of opportunity [and] show applied knowledge of the significance of poverty, racism, ill health and disability, gender, social class [and] sexual orientation in managing the assessment process. (TCSW, 2012, p.11) 
Practice educators can be off-site (based outside the placement agency) or on-site (based within the placement agency) and the configuration of the supervisory arrangement is an area requiring significant consideration if students are not to be disadvantaged (Zuchowski, 2014).

This current paper aims to add to the literature about strategies which enhance the practice learning outcomes of black African students of social work in English HEIs. It is in the interest of HEIs to understand the specific challenges faced by this minority group in their pursuance of improved educational outcomes as well as good progression and attainment rates.

\section{Benefits of a positive placement experience}

Bellinger (2010) found that social work placements tend to have a more lasting and profound impact on students than teaching delivered within the classroom setting and Doel (2010) concurs. Such views are significant for this study in that while positive, enjoyable placements will be remembered with excitement, poor or negative experiences may be remembered with anger or disappointment but also could result in longer-term feelings of hurt and emotional distress.

Shola and Ramatu have proposed a number of strategies, which in their view can enhance placement experiences for students of black African origin. Every social work student matters and positive placement experiences can only serve to reinforce the profession's commitment to antioppressive and anti-discriminatory practice learning. There are ultimate benefits for the student, the university and the social work profession when students' learning journeys, which overall have consisted of experiences which enhance their well-being and self-discipline, build their confidence and competence. It is important to make a distinction here between positive placement experiences and successful placement outcomes. It is the view of the author that a student can 'fail' a placement but have experienced the placement as positive. It is also significant to state that BME students in higher education (HE) have persistently reported less satisfaction with their student experience than white colleagues (HEFCE, 2010; NUS, 2011). These trends have implications for access, and the recruitment and retention of BME students.

134 J. of Practice Teaching \& Learning 13(2-3), pp.130-145. @ w\&b 


\section{Research design}

A purposive sampling strategy was used to recruit two participants for a pilot of a larger doctoral study into the experiences of black African students on social work placements in England. Such a strategy guaranteed participants of a certain profile who could assist in addressing the research aims and objectives. Participants had to 1) be enrolled on social work programmes in England 2) be studying at MA or BA level 3) self-identify as black African 4) not be studying at the researcher's university and 5) have experience of practice learning, and could be either male or female. This qualitative study sought to understand from the perspective of the participants their experiences of practice learning in England. A major limitation of this study was the reliance on self-reporting from participants and also the very small number of participants $(n=2)$. These limitations, however, do not undermine the quality of information and the contribution of knowledge to this area of social work education.

The participants were asked to comment directly on factors which enhanced or inhibited positive placement experiences. Their responses were thematically coded into three main categories: the role of the student, the HEI and the PE, which form the essence of this paper and will now be discussed.

\section{The role of the student}

Black African students on social work programmes have a role to play in changing and improving their experiences in the practice learning environment. Ramatu and Shola suggest that black African students should ensure that they go into placement 'with an open mind'. By this they mean that students should not try to form opinions about the placements they have been allocated as this could result in preconceived ideas about what the placement might or might not be able to offer. In addition, contrary to the popular belief that asking questions raises doubts in PEs' minds about the abilities of specific students, a clear recommendation from the participants is to seek answers to questions wherever possible from PEs. They stress that it is important that 'if you don't know, ask' as not asking can give the impression that the student completely understands the placement, their role and tasks and PEs may not be as accommodating when things

135 J. of Practice Teaching \& Learning 13(2-3), pp.130-145. @ wEb 
go wrong. Of course, students ought to be cautious about how much support they require from their PEs and others on placement as this can be interpreted as students being overly dependent.

Of particular significance for the participants was the view that often African people are perceived as resilient and strong, and the view of black women particularly as matriarchs who work and fight until the bitter end (Reynolds-Dobbs et al, 2008). There is also the fear of being perceived as incapable or of fulfilling a stereotype (Johnson-Ahorlu, 2012). The respondents here warn against this approach and propose that the 'I go do am' (pidgin for 'I will succeed') syndrome should be discouraged as it gives the impression of superwomen who can handle any situation and circumstance and does not fully acknowledge human vulnerabilities and weaknesses and the impact of emotional and challenging circumstances. Such a view is reinforced by black African students who feel they need to work twice as hard as students of other ethnicities (Reynolds-Dobbs, 2008). Shola feeling that having a 'thick skin for resilience' and Ramatu's view that 'you want to be resilient and wait till the end of the placement', highlight the way in which these two students regarded resilience as a useful trait to have whilst on placement. Closely linked to this is the lack of willingness by some black African students to discuss their concerns with others. Shola stated the need to 'confide in somebody where possible', a strategy which could become useful if ever there were to be difficulties later on in the placement. This is perhaps where the student's relationship with the PE is crucial, and where the issues relate to the $\mathrm{PE}$, a clear process for discussing placement concerns should be available to all students.

In terms of communication, Ramatu advises clarity of speech at all times. She recognises the need to 'be clear in your speech' and to 'be sure people have understood you'. Whilst every person has an accent, the African accent in the UK appears to have come up against significant ridicule, criticism and negativity (Fairtlough et al, 2013) and resulted in the PE abruptly ending a telephone discussion with Ramatu allegedly due not being able to understand her accent (Tedam, 2014).

\section{The role of higher education institutions}

HEIs play a central role in ensuring that their social work students' experiences, both in the classroom and in the field, are of a high standard.

136 J. of Practice Teaching E Learning 13(2-3), pp.130-145. (C) wEb 
Finch (2014) examines the conflict that can exist between HEI systems and placements and concludes that the 'tendency for universities to treat the placement module like any other academic module with automatic rights' (p.11) to re-take failed placements is concerning. Ramatu and Shola suggest that HEIs should be cautious about their placement providers and should care enough to ensure that rigorous quality assurance processes are adhered to. Shola comments that 'some placements are notorious for stressing students out'.

Shola's suggestion of 'notoriety' implies the possibility that a consistent pattern amongst some placement settings impacts on the well-being of students. A clear and consistently applied quality assurance and matching process could minimise the impact of such placements although it is acknowledged that by their very nature, social work placements should offer challenging and complex experiences for students, appropriate to their level of study. In addition to this Shola, referring to her own experience of a nearly failed placement, concludes that the absence of a monitoring and evaluation process meant she was placed with a PE who had a history of failed students, all of black minority ethnicity. She states that 'the university should have known that this PE had previously failed three black students.

Unfortunately, the university did not address this until a recommendation to fail Shola's placement was investigated and subsequently overturned.

Whilst it is difficult and perhaps unfair to conclude that Shola's PE is racist, the question remains to be asked about how such a pattern was allowed to continue and what the likely implications would have been if Shola had faced a similar failed outcome which had not been investigated by her HEI. Practice educator practice standards (PEPS) and values, which are now firmly embedded in PE training and practice, require PEs to assess in a manner which does not stigmatise students due to race, disability, gender or other differences, mentioned earlier.

The issue of identifying and allocating placements to BME students has been highlighted by Fairtlough et al (2013) as difficult due to 'placement shortages' (p.9) and in areas which students 'perceived to be racist' (p.10), for example in areas with high representation of British National Party (BNP) sympathisers. This latter view is consistent with Ramatu's view that HEI's 'should be more careful about where they place black students'.

This should not be an onerous task if HEIs and placement teams have maintained an up-to-date database of PEs who have successfully worked with black African students. It is important to state that successfully working with a student does not necessarily mean that the student had

137 J. of Practice Teaching \& Learning 13(2-3), pp.130-145. @ wE-b 
a successful outcome; rather it is indicative of a professional relationship which did not break down. In the absence of such a database, ongoing generic and bespoke training and support should be available for PEs and organisations that take on students from a range of backgrounds. The content of such training should be informed by relevant contemporary research.

\section{PEs and others involved in practice learning}

The main role of practice educators is to support and assess trainee social workers during placements. They are responsible for the student's learning and assessment, utilising information from their own assessment and other sources (such as service-user feedback) to reach a recommendation about the student's competence (TCSW, 2012).

It has been argued elsewhere that the relationship between the PE and the student is of immense importance in practice education (Tedam, 2012b) and there are tools and strategies available to support the building and maintaining of relationships between PEs and their students more generally (Doel, 2010; Davys and Beddoe, 2009) and for black African students of social work more specifically (Tedam, 2012b). Considerable time will have to be invested in the development of the PE-student relationship and once this is formed can have progressive and positive implications for the practice learning experience. Research by Levrefre (2005) suggests that where a positive working relationship exists between the student and their PE, a recommendation of failed placement is more likely to be accepted by the student than where there have been difficulties.

PEs should, among others, possess enabling and empowering skills, should be supportive, encouraging, transparent and honest. Contrary to what is generally perceived as good practice, Ramatu's PE is alleged to have commented in relation to a written piece of work given to her to review, that 'this should be in the bin'. Such comments are contrary to the positive, empowering values expected of a PE who is in effect trying to enable the learning of another. The connotations of this statement were far reaching for Ramatu, who by the end of her placement, stated that she 'took feedback well, but struggled with insults'.

No student, whatever their level of competence, should be subjected to this overt show of disrespect and emotional assault, which according

138 J. of Practice Teaching \& Learning 13(2-3), pp.130-145. @ w\&b 
to Johnson-Ahorlu (2012), for any black student, can be viewed as the inhumane and callous consequence of racism. Sue (2005) refers to this kind of behaviour as 'micro aggressions' which are manifested through daily interactions where one's membership of a minority group results in being disparaged and maligned. That a completed piece of work deserved to be put in the bin is clearly not feedback, even if intended to be. It is concerning that the PE did not choose a more respectful and sensitive way of giving feedback. However, without knowledge of their specific training and assessment content, it is not possible to conclude either way whether there is an ongoing training and development need for this particular PE.

The general attitudes of the PE and some colleagues contributed to Ramatu feeling isolated within the agency and team where she was placed. She stated that she 'didn't feel included', a situation which many students experience and which is not conducive to learning. According to Probyn (1996, p.8), 'if you have to think about belonging, perhaps you are already outside'. For Ramatu, exclusion came in many guises: her accent, her written work and her physical presence in an organisation where she felt unwelcome. Doel (2010) suggests that PEs can attempt to minimise BME students' isolation by signposting or recommending specific support groups.

The irony was that Ramatu was in this placement to learn and yet she questioned a number of times during her interview, 'where is the learning?'. This leads one to conclude that she did not feel she learned much from the placement but rather worked at maintaining professionalism whilst she navigated persistent acts of oppression.

PEs are central to the professional socialisation of social work students in that they model and prepare students using social work values, skills and competencies, which Page (2005) argues is essential for growth and development. Ramatu reflects on what a positive placement experience might look like and suggests:

A positive placement experience really has got to do with getting a lot of support from whoever is your mentor, given that they know you are in the learning process. 


\section{Implications for social work education}

Stakeholders involved in the support and development of students in practice learning may have their own views and ideas about what is causing the differences in progression and attainment of specific minority groups studying social work. Participants in this study did not neglect the role of the student when highlighting strategies that might be helpful; instead they placed a significant burden of the strategy on themselves as social work students.

Tedam (2012a, 2012b and 2013) attempted to contribute to remedying the shortage of culturally relevant teaching and learning materials for black African students of social work in the hope that practice educators specifically and social work educators more generally would find them useful.

Ramatu's view that a social work student can be judged 'because you come from Africa, because you look different and it's already stereotyping you that you have nothing to offer' challenges social work educators to continuously reflect on their teaching practices, be aware of unconscious bias, be fair in their work with students, ensure transparency and avoid behaviours that could be construed as racist, work to the PEPS and ensure placement matching is carefully undertaken.

The Social Work Task Force reported in 2009 its concerns about the quality and robustness of assessment, which it viewed as allowing incompetent students to pass. The subsequent changes to social work education included a focus on practice education and learning.

Social work educators should encourage and promote strategies and processes which facilitate and ensure positive practice learning experiences for students. To do this, the author proposes a SEER (sensitive, empowering, encouraging and respectful) approach to supporting students. This tactful approach can minimise the impact of having to fail a student and can also lay the foundation for ongoing work with marginal or failing students. Such a strategy complements the practice educator values (TCSW, 2012), minimises the potential for deficit-oriented language and approaches, and models good social work practice.

Every student has the potential to succeed despite the challenges and struggles they might have whilst on placement. Difficult experiences can enhance their problem-solving skills, assist them to identify and understand their strengths and areas for development, and enable them to act in ways which can contribute to successful outcomes. Where students are clearly

140 J. of Practice Teaching \& Learning 13(2-3), pp.130-145. @ w w -b 
not meeting qualifying requirements in terms of the PCF, Health and Care Professions Council standards of proficiency or are involved in other fitnessto-practise procedures, honest discussions should be held and evidence to support a failed placement be provided. Evidence collated at specific points during placement and which provides a broad view of a student's journey can and should be used to support a PE's recommendation for failing a student's placement. This approach could minimise a PE's anxiety when working with failing or marginal students (Finch, 2014).

\section{Conclusion}

The commitment and contribution by PEs to social work education cannot be overemphasised and it is acknowledged that they create "contexts in which student's desire and ability to learn can work most effectively' (Walker et al 2008, p.61). PEs also manage the 'triadic dynamics' between the student, themselves and the university tutor (Finch and Taylor 2013, p.254) which is not always without its challenges. It is not the intention of this paper to undermine these efforts; however it needs to be stated that there are some PEs whose engagement and treatment of BME students will be perceived as less favourable, oppressive and with failure outcome that has been 'fast-tracked' (Tedam 2012b, p.24).

This article has presented a number of strategies which students of black African origin have proposed as useful for facilitating and enhancing not only their experiences of practice learning but also progression and attainment in their social work training. Listening to participants frame their particular experience as painful and traumatic has motivated wider dissemination of these strategies. The participants, in the author's view, propose strategies that are well within what should be considered good practice.

141 J. of Practice Teaching \& Learning 13(2-3), pp.130-145. @ w\&b 


\section{References}

Bartoli, A. (2013) (Ed.) Anti-racism in Social Work Practice. St. Albans: Critical Publishing

Bartoli, A., Kennedy, S. and Tedam, P. (2008) Practice learning: Who is failing to adjust? Black African student experience of practice learning in a social work setting. Journal of Practice Teaching and Learning, 8, 2, 75-90

Bellinger, A. (2010) Talking about (re)generation: Practice learning as a site of renewal for social work. British Journal of Social Work, 40, 8, 2450-2466

Bernard, C., Fairtlough, A., Fletcher, J. and Ahmet, A. (2011) Diversity and Progression among Social Work Students in England. Goldsmiths University of London [Accessed 27 December 2013 at http://www.kcl.ac.uk/sspp/policyinstitute/scwru/dhinitiative/projects/bernardetal2011diversityfinalreport.pdf]

Bernard, C., Fairtlough, A., Fletcher, J. and Ahmet, A. (2013) A qualitative study of marginalised social work students' views of social work education and learning. British Journal of Social Work [Accessed 21 January 2015 at doi: 10.1093/bjsw/ bct055]

College of Social Work (TCSW) (2012) Practice Educator Professional Standards for Social Work. London: TCSW. [Accessed 11 January 2015 at http://www.tcsw. org.uk]

College of Social Work (TCSW) (2012) Professional Capabilities Framework. [Accessed 11 January 2015 at http://www.tcsw.org.uk/pcf.aspx]

Davys, A.M. and Beddoe, L. (2009) The reflective learning model: Supervision of social work students. Social Work Education, 28, 8, 919-933

Dhanda, M. (2010) Understanding Disparities in Student Attainment: Black and minority ethnic students' experience. University of Wolverhampton. [Accessed 2 January 2015 at http://www2.wlv.ac.uk/equalopps/mdsummary.pdf]

Doel, M. (2010) Social Work Placements: A traveller's guide. London: Routledge

Fairtlough, A., Bernard, C., Fletcher, J. and Ahmet, A. (2013) Black social work students' experiences of practice learning: Understanding differential progression rates. Journal of Social Work, 14, 6, 605-624. [Accessed 21 January 2015 at doi: 10.1177/1468017313500416]

Field, P., Jasper, C. and Littler, L. (2014) Practice Education in Social Work: Achieving professional standards. Critical skills for social work. Northwich: Critical Publishing

Finch, J. (2014) 'Running with the fox and hunting with the hounds': Social work tutors' experiences of managing failing social work students in practice learning settings. British Journal of Social Work, 44, 8 [Accessed 21 January 2015 at doi: 10.1093/bjsw/bcu085]

Finch, J. and Taylor, I. (2013) Failure to fail? Practice educators' emotional

142 J. of Practice Teaching \& Learning 13(2-3), pp.130-145. @ w w -b 
experiences of assessing failing social work students. Social Work Education: The International Journal, 32, 2, 244-258

Fletcher, J., Bernard, C., Fairtlough, A. and Ahmet, A. (2013) Beyond equal access to equal outcomes: The role of the institutional culture in promoting full participation, positive intergroup interaction and timely progression for minority social work students. British Journal of Social Work, 45, 1 [Accessed 30 July 2015] at http://dx.doi. org/10.1093/bjsw/bct081]

Gair, S., Miles, D., Savage, D. and Zuchowski, I. (2014) Racism unmasked: The experiences of Aboriginal and Torres Strait Islander students in social work field placements. Australian Social Work, [Accessed 19 July 2014 at DOI: 10.1080/0312407X.2014.928335]

Goldingay, S. (2012) Getting it right in the mix: Teaching social work practice skills inclusively to diverse student groups. Journal of Social Inclusion, 3, 1, 101-116

GSCC (2012) A Report on Social Work Education in England 2009-2010. London: General Social Care Council

Hair, H.L. and O'Donoghue, K. (2009) Culturally relevant, socially just social work supervision: Becoming visible through a social constructionist lens. Journal of Cultural and Ethnic Diversity in Social Work, 18, 1-2, 70-88

Higher Education Funding Council for England (HEFCE) (2010) Student Ethnicity: Profile and progression of entrants to full-time, first degree study. [Accessed 11 January 2015 at http://www.hefce.ac.uk/pubs/year/2010/201013]

Hussein, S., Moriarty, J. and Manthorpe, J. (2009) Variations in Progression of Social Work Students in England: Using student data to help promote achievement: Undergraduate full-time students' progression on the social work degree. Social Care Workforce Research Unit, King's College London [Accessed 27 December 2013 at http://www.kcl.ac.uk/sspp/policy-institute/ scwru/pubs/2009/husseinetal2009Variations.pdf

Hussein, S., Moriarty, J., Manthorpe, J. and Huxley, P. (2008) Diversity and progression among students starting social work qualifying programmes in England between 1995 and 1998: A quantitative study. British Journal of Social Work, 38, 8, 1588-1609

Johnson-Ahorlu, N.R. (2012) The academic opportunity gap: How racism and stereotypes disrupt the education of African American undergraduates. Race Ethnicity and Education, 15, 5, 633-652

Jones, R. and Thomas, L. (2005) The 2003 UK government higher education paper: A critical assessment of its implications for the access and widening participation agenda. Journal of Educational Policy, 20, 5, 615-630

Lefevre, M. (2005) Facilitating practice learning assessment: The influence of relationship. Social Work Education, 24, 5, 565-583

143 J. of Practice Teaching \& Learning 13(2-3), pp.130-145. ๑ wE-b 
NUS (2011) Race for Equality: A report on the experiences of Black students in further and higher education. National Union of Students [Accessed 3 January 2015 at http://www.nus.org.uk/PageFiles/12350/NUS_Race_for_Equality_web. pdf]

Page, G. (2005) Professional socialisation of valuers: What the literature and professional bodies offer. International Education Journal, special issue, 5, 5, 105-116

Probyn, E. (1996) Outside Belongings. London and New York: Routledge

Reynolds-Dobbs, W., Thomas, K.M. and Harrison, M.S. (2008) From Mammy to Superwoman. Images that hinder Black women's career development. Journal of Career Development, 35, 2, 129-150

Richardson, J.T.E. (2008) The attainment of ethnic minority students in higher education. Studies in Higher Education, 33, 1, 33-48

Shiner, M. and Modood, T. (2002) Help or hindrance? Higher education and the route to ethnic equality. British Journal of Sociology of Education, 23, 2, 209-232

Singh, G. (2011) Black and Minority Ethnic (BME) Students' Participation in Higher Education: Improving retention and success. York: The Higher Education Academy

Social Work Task Force (SWTF) (2009) Facing up to the Task: The interim report of the Social Work Task Force: July 2009. London: Department of Health and Department for Children, Schools and Families

Sue, D.W. (2005) Racism and the conspiracy of silence. Counselling Psychologist, 33, $100-114$

Tedam, P. (2012a) Using culturally relevant case studies to enhance students' learning: A reflective analysis of the benefits and challenges for social work students and academics. Enhancing the Learner Experience in Higher Education, 4, 1, 59-69

Tedam, P. (2012b) The MANDELA model of practice learning: An old present in new wrapping. Journal of Practice Teaching and Learning, 11, 2, 19-35

Tedam, P. (2013) What can social workers learn from African proverbs? Journal of Practice Teaching and Learning, 12, 1, 17-32

Tedam, P. (2014) When failing doesn't matter: A narrative inquiry into the practice learning experiences of black African social work students in England. International Journal of Higher Education, 3 (1) 136-145

Thomas, L. (2012) Building Student Engagement and Belonging in Higher Education at a Time of Change: Final report from the What Works? Student Retention \& Success programme. [Accessed 21 January 2015 at https://www. heacademy.ac.uk/sites/default/files/What_works_final_report_0.pdf]

Valentine, D. (2004) Field education: Exploring the future, expanding the vision.

144 J. of Practice Teaching \& Learning 13(2-3), pp.130-145. @ w\&b 
Journal of Social Work Education, 40, 1, 3-11

Walker, J., Crawford,K., Parker, J. (2008) Practice Education in Social Work. A handbook for practice teachers, assessors and educators. Exeter: Learning Matters

Walter, M., Taylor, S. and Habibis, D. (2011) How White is social work in Australia? Australian Social Work, 64, 1, 6-19

Yorke, M. and Longden, B. (2008) The First Year Experience of Higher Education in the UK: Final report. York: The Higher Education Academy

Zuchowski, I. (2014) Getting to know the context: The complexities of providing off-site supervision in social work practice learning. British Journal of Social Work [Accessed 21 January 2015 at doi: 10.1093/bjsw/bcul33] 